\title{
Accumulation and distribution of micronutrients in banana cv. Williams (Musa AAA Simmonds) with different doses of nitrogen
}

\section{Acumulación y distribución de micronutrientes en banano cv. Williams (Musa AAA Simmonds) bajo diferentes dosis de nitrógeno}
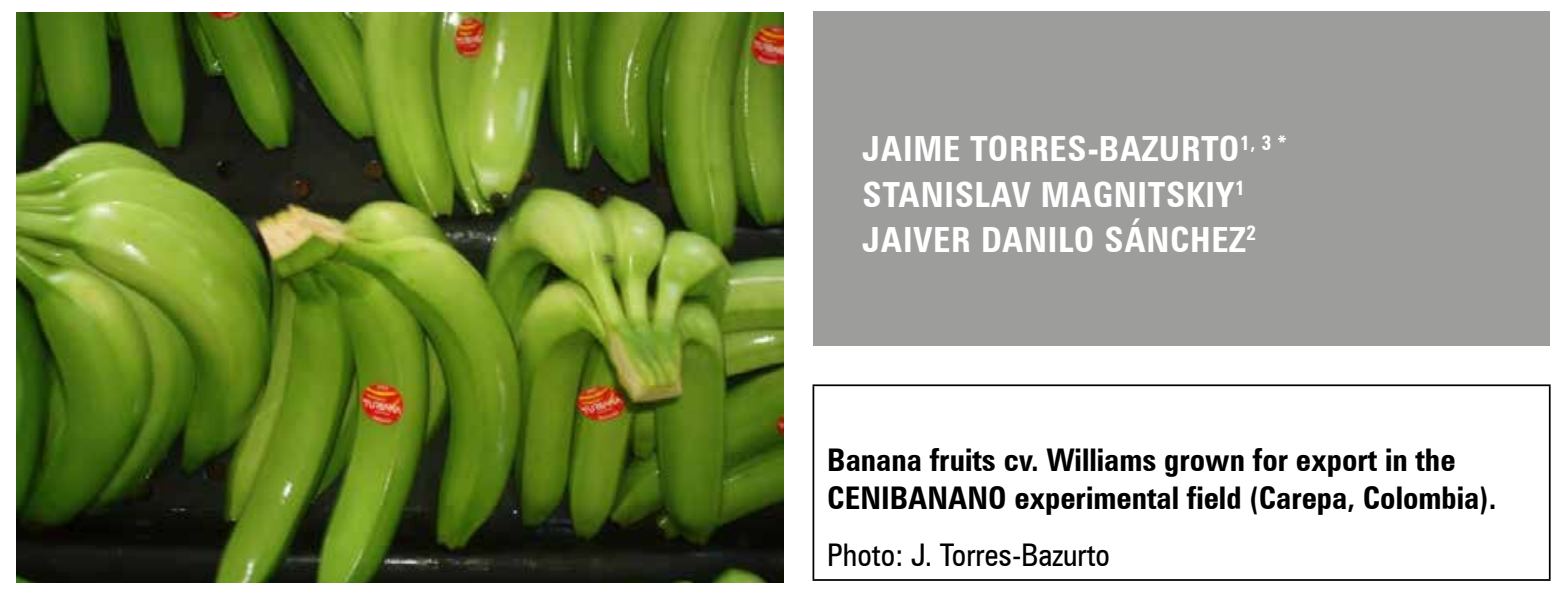

Banana fruits cv. Williams grown for export in the CENIBANANO experimental field (Carepa, Colombia).

Photo: J. Torres-Bazurto

\section{ABSTRACT}

This research evaluated the effect of nitrogen fertilization $\left(0,161,321.8\right.$, or $\left.483 \mathrm{~kg} \mathrm{ha}^{-1}\right)$ on the accumulation of $\mathrm{Fe}, \mathrm{Cu}, \mathrm{Zn}, \mathrm{Mn}$, and $\mathrm{B}$ in banana plants cv. Williams in two production cycles in Uraba, Colombia. The micronutrient accumulation models for the plants were obtained with a multivariate approach for differences between cycles, using a randomized complete block design with repeated measurements over time. The $\mathrm{N}$ doses with greater accumulation of $\mathrm{Cu}, \mathrm{Fe}, \mathrm{Mn}, \mathrm{Zn}$ and $\mathrm{B}$ in the plants with fruits were 321.8 and $483 \mathrm{~kg} \mathrm{ha}^{-1}$. The average sequence of micronutrient extraction by whole plants was $\mathrm{Fe}>\mathrm{Mn} \geq \mathrm{Zn}>\mathrm{B}>\mathrm{Cu}$ in the first cycle and $\mathrm{Fe}>\mathrm{Cu}>\mathrm{Mn} \geq \mathrm{Zn}>\mathrm{B}$ in the second cycle. The micronutrient accumulation was organ-specific and varied depending on the stage of development. Fe was the major micronutrient extracted by the corm, pseudostem, and bunch. The leaves had the greatest accumulation of $\mathrm{Mn}$. The higher fertilizer doses generated a major response in terms of micronutrient extraction by the banana plants.

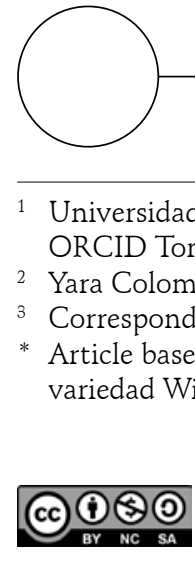

Additional keywords: fertilization; nutrient partitioning; mineral nutrition; Musaceae.

Universidad Nacional de Colombia, Facultad Ciencias Agrarias, Departamento de Agronomía, Bogota (Colombia). ORCID Torres-Bazurto, J.: 0000-0002-4731-650X; ORCID Magnitskiy, S.: 0000-0002-3715-1932

Corresponding author. jtorresb@unal.edu.co

Article based on the PhD thesis of the first author "Absorción, distribución y acumulación de nitrógeno en banano variedad Williams en dos ciclos de producción en zona húmeda tropical". 


\section{RESUMEN}

La presente investigación evaluó el efecto de diferentes dosis de fertilización nitrogenada $(0,161,321,8$ o $483 \mathrm{~kg}$ ha $^{-1}$ ) sobre la acumulación de Fe, Cu, Zn, Mn y B en plantas de banano cv. Williams durante dos ciclos productivos en el Urabá, Colombia. Los modelos de acumulación de micronutrientes en plantas se obtuvieron mediante un enfoque multivariado de las diferencias entre ciclos, empleando un diseño de bloques completos al azar con medidas repetidas en el tiempo. Las dosis de $\mathrm{N}$ que mejor comportamiento mostraron para la acumulación de $\mathrm{Cu}, \mathrm{Fe}, \mathrm{Mn}$, Zn y B en las plantas, incluidos los frutos, fueron 321,8 y $483 \mathrm{~kg} \mathrm{ha}^{-1}$. La extracción de micronutrientes por plantas completas tuvo el siguiente orden $\mathrm{Fe}>\mathrm{Mn} \geq \mathrm{Zn}>\mathrm{B}>\mathrm{Cu}$ para el primer ciclo y $\mathrm{Fe}>\mathrm{Cu}>\mathrm{Mn} \geq \mathrm{Zn}>\mathrm{B}$ para el segundo ciclo. La acumulación de micronutrientes fue específica a cada órgano y varió según la etapa de desarrollo, siendo el Fe el principal micronutriente extraído por el cormo, el pseudotallo y el racimo, mientras que las hojas presentaron la mayor acumulación de $\mathrm{Mn}$. Las mayores dosis de fertilizantes resultaron en la mayor respuesta en la extracción de micronutrientes por las plantas de banano.

Palabras clave adicionales: fertilización; partición de nutrientes; nutrición mineral; Musaceae.

Received: 28-09-2020 Accepted: 02-12-2020 Published: 21-01-2021

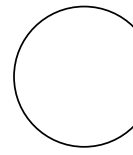

\section{INTRODUCTION}

Musa sp. crops are vital for the diet of approximately 400 million people worldwide (Perea, 2003). In Colombia, the income of about 150 thousand families depends on the production of banana for export (Red Agricola, 2020), and Uraba is the principal producing region of the country. About $85 \%$ of the current Uraba economy is based on the production of exporttype bananas, mainly the Cavendish subgroup Musa AAA Simmonds (Red Agricola, 2020). However, various socio-economic and technical problems affect the cultivation of bananas in the area (Gutiérrez et al., 2017; AUGURA, 2020).

One of the serious technical challenges that affect banana productivity is the adjustment of fertilizer doses (Alcaraz and Jiménez, 2018; Torres et al., 2019). In Uraba, nitrogen is the key element in fertilizer doses based on crop requirements per stage of development (Torres et al., 2019; AUGURA, 2020). Nitrogen is assimilated by banana plants mainly in the form of nitrate or ammonium (Sánchez and Mira, 2013; Keshavan et al., 2014). The requirements of banana crops are considered high, exceeding $200 \mathrm{~kg} \mathrm{ha}^{-1}$ year $^{-1}$ of $\mathrm{N}$ (Sánchez and Mira, 2013). According to Marschner (2012), the optimal content of $\mathrm{N}$ for adequate plant growth is between 2 and 3\% of dry weight (DW). Robinson and Galán (2012) reported an optimal N content in banana leaves ranging from 2.5 to $3 \%$ DW.

Nutrient extraction curves in plants are useful for defining optimal doses of macro- and micronutrients
(Medina, 2010; Jeyabaskaran et al., 2018). The extraction of mineral nutrients should be studied in banana plants taking into account the sink-source relationships, such as between the mother plant and suckers (Guimarães et al., 2020; Turner et al., 2020). Some regional studies on banana $\mathrm{cv}$. Williams have defined $\mathrm{N}$ extraction levels at harvest, which could be used for determining fertilizer doses (Soto, 2001). In Colombia, one the first studies on nutrient extraction by banana plants was done by Martínez (2006) for cvs. Gran Enano and Valery in Uraba, which posed the question: what is the effect of $\mathrm{N}$ fertilizer rates on the accumulation and distribution of micronutrients in banana plants?

This question should be answered by taking into account the importance of micronutrients in banana growth (Torres, 2016). Micronutrient applications affect the growth of leaves (Souza et al., 2016), roots (Liu et al., 2019), and pseudostems (Kumar et al., 2020) and banana production (Robinson and Galán, 2012). The contents of $\mathrm{Fe}, \mathrm{Mn}, \mathrm{Zn}, \mathrm{Cu}$, and $\mathrm{B}$ in plant organs estimate the plant nutrient status with the DRIS method (Villaseñor et al., 2020). The concentrations of $\mathrm{Mn}$ and $\mathrm{B}$ in banana leaves may correlate with chlorophyll contents (Arantes et al., 2016), and micronutrient allocation to fruits is required for bunch development (Soto, 2001). However, excess Fe, $\mathrm{Mn}$, and $\mathrm{Cl}$ in coastal tropical soils could negatively affect yields (Osorio, 2014; Villaseñor et al., 2020). 
Few studies have addressed micronutrient accumulation in banana plants as affected by macronutrient fertilizers. In Brazil, Borges et al. (2006) compared foliar contents of the microelements $\mathrm{B}, \mathrm{Cl}, \mathrm{Cu}, \mathrm{Fe}, \mathrm{Mn}$, and $\mathrm{Zn}$ in 24 genotypes in two production cycles that had an annual addition of $100 \mathrm{~kg} \mathrm{~N} \mathrm{ha}^{-1}, 40 \mathrm{~kg} \mathrm{P}_{2} \mathrm{O}_{5}$ $\mathrm{ha}^{-1}$, and $300 \mathrm{~kg} \mathrm{~K}_{2} \mathrm{O} \mathrm{ha}^{-1}$. The genotypes differed in terms of micronutrient extraction by the leaves. In addition, each genotype had an accumulation that varied between the cycles, with lower levels of $\mathrm{Cl}, \mathrm{B}$, $\mathrm{Fe}$, and $\mathrm{Zn}$ in the second cycle; the leaf contents substantially varied for $\mathrm{Mn}\left(43-574 \mathrm{mg} \mathrm{kg}^{-1}\right)$ and Fe 56$212 \mathrm{mg} \mathrm{kg}^{-1}$ (Borges et al., 2006). Robinson and Galán (2012) stated that genotype plays a key role in the absorption and foliar accumulation of micronutrients, and that these processes are influenced by edaphoclimatic conditions and fertilizer practices. The aim of this research was to evaluate the accumulation and distribution of the micronutrients $\mathrm{Fe}, \mathrm{Mn}, \mathrm{Zn}, \mathrm{Cu}$, and B in banana cv. Williams (Musa AAA Simmonds) as affected by different doses of $\mathrm{N}$ fertilizers in the Uraba region of Colombia.

\section{MATERIALS AND METHODS}

\section{Experiment location and climatic conditions}

This research was conducted in 2011-2012 in the Uraba region of the Antioquia department, Colombia, using the experimental field of AUGURA (Carepa, Antioquia), lots 3 and 4, $7^{\circ} 46^{\prime} 46^{\prime \prime} \mathrm{N}$ and 76 $46^{\prime} 20^{\prime \prime}$ $\mathrm{W}$ and $20 \mathrm{~m}$ a.s.l. The soils were fine Fluventic Eutrudepts, clay loam, over clay Fluvaquentic Eutrudept, and fine loam Vertic Endoaquept, according to USDA classifications (Soil Survey Staff, 2014). In the soils, the $\mathrm{pH}$ ranged from 5.2 to 6.2 , the average $\mathrm{N}$ contents was $0.36 \%$, the contents of $\mathrm{Ca}, \mathrm{Mg}$, and $\mathrm{K}$ were 15.8, 5.9, and $0.44 \mathrm{cmol}_{\mathrm{c}} \mathrm{kg}^{-1}$, respectively, and the $\mathrm{P}$ content was $8.25 \mathrm{mg} \mathrm{kg}^{-1}$. The micronutrient contents $\left(\mathrm{mg} \mathrm{kg}^{-1}\right)$ in the soils were 4.35-6.67 for $\mathrm{Cu}$, 72.2-148.9 for Fe, 13.3-72.6 for $\mathrm{Mn}, 0.79-1.70$ for $\mathrm{Zn}$ (DTPA extraction), and 0.22-0.34 for B (Azomethine$\mathrm{H}$ method) (IGAC, 2006).

The following climatic conditions were registered during the experiment: $23.2^{\circ} \mathrm{C}$ minimum and $32.3^{\circ} \mathrm{C}$ maximum air temperatures; $26.7^{\circ} \mathrm{C}$ average air temperature (with $27^{\circ} \mathrm{C}$ regional average); $87 \%$ relative air humidity, which coincided with the annual average; and $5 \mathrm{~h} \mathrm{~d}^{-1}$ average solar brightness, totaling 1700 $\mathrm{h}$ year ${ }^{-1}$. The annual precipitation was $845 \mathrm{~mm}$ during the first production cycle (August 2011-April 2012) and 2,088 $\mathrm{mm}$ during the second production cycle (February 2011-December 2012). The rainfall was low from January to March (1.4-30.4 mm month ${ }^{-1}$ ), which corresponded to a "dry season", typical for the region.

\section{Plant material and treatments}

Banana plants (Musa AAA Simmonds) from the AAA group, Giant Cavendish subgroup, Williams clone in the $6^{\text {th }}$ productive cycle were used. The plants had an average height of $3.5 \mathrm{~m}$. The sowing distance was $2.5 \times 2.5 \mathrm{~m}$, with approximately 1,600 plants/ha. The agronomic management for commercial banana plantations in Uraba was used, except for the fertilizer doses.

The fertilization system recommended by Cenibanano for the region was applied taking into account the plant nutrient requirements and the results of the soil analysis (Sánchez and Mira, 2013). The five treatments were: absolute control (no fertilizer applied), 0, 161, 321.8, and $483 \mathrm{~kg} \mathrm{ha}^{-1}$ of N. Additionally, all plants, except the absolute control, received the following amounts of fertilizers per ha: $87.1 \mathrm{~kg}$ $\mathrm{P}_{2} \mathrm{O}_{5}, 678.8 \mathrm{~kg} \mathrm{~K} \mathrm{O}_{2}, 50.5 \mathrm{~kg} \mathrm{CaO}, 117.5 \mathrm{~kg} \mathrm{Mg}, 64.2 \mathrm{~kg}$ $\mathrm{S} ; 1.4 \mathrm{~kg} \mathrm{~B}$, and $9.3 \mathrm{~kg} \mathrm{Zn}$. The sources of the mineral fertilizers were urea, $\mathrm{K}-\mathrm{Mag} \circledast{ }^{\circledR}\left(22 \% \mathrm{~K}_{2} \mathrm{O}, 18 \% \mathrm{MgO}\right.$, and $22 \% \mathrm{~S})$, Fertiboro $(10 \% \mathrm{~B})$, Solufos $\left(30 \% \mathrm{P}_{2} \mathrm{O}_{5}\right.$, $36 \% \mathrm{Ca}, 5 \% \mathrm{~S}$, and $8 \% \mathrm{Si}$ ), $\mathrm{ZnO}, \mathrm{K}_{2} \mathrm{SO}_{4}$, and $\mathrm{KCl}$. The fertilizer doses were fractionated within each production cycle, for a total of 17 fertilizer applications per year, with approximately 3 weeks between applications. The fertilizer applications started with the flowering of the crop, when fertilization of the ratoon traditionally begins in the region.

\section{Experiment establishment}

In the field, the soil-spatial variability was considered, establishing four in-space replicates (blocks), with the treatments randomized within the blocks. The blocks were distributed based on the soil taxonomic units, and each block had a complete set of treatments. Each treatment matched the unit called "botalon", which was $1563 \mathrm{~m}^{2}$ area and had 250 banana plants. Fifteen plants were selected within each "botalon" by height (between 1.0 and $1.5 \mathrm{~m}$ ), forming the experiment unit. The evaluations were performed after a certain number of weeks that corresponded to $50 \%$ of the plants reaching the following phases of 
growth: vegetative growth (weeks 17-18), flower differentiation (weeks 22-23), flowering (weeks 39-40), bunch filling (weeks 43-44), and harvest (weeks 5051). The fruit filling and harvest in the first production cycle overlapped with the vegetative growth and flower differentiation of the second cycle.

The sampling was done at least two weeks after the fertilizer applications. The plants were dissected into organs and dried in oven at $65^{\circ} \mathrm{C}$ for $48 \mathrm{~h}$. The micronutrient contents were quantified in the Soil and water laboratory of the Facultad de Ciencias Agrarias, Universidad Nacional de Colombia (Bogota), using the standardized methods of analysis (IGAC, 2006).

\section{Statistical analysis}

A completely randomized block design was used with five fertilizer treatments and four replicates to assess the micronutrient accumulation in the plants. The multivariate analysis was used to evaluate the variance of the repeated measures design, where the treatments and replicates were two factors betweenthe-subjects, the production cycle was an intra-subject factor, and the blocks were associated with the soil spatial variability in the field, which helped adjust the model.

The micronutrient accumulations per organ and phenological stage were approached with a principal component analysis and multivariate analysis (Johnson and Wichern, 2007). To evaluate only the changes between the fertilizer treatments and eliminate the cycle effects, the differences between the cycles were considered for each variable. The principal component analysis determined the number of components for use in the multivariate models defined for the treatments to establish the variables with the best fit per model. The accumulation of $\mathrm{Fe}, \mathrm{Mn}, \mathrm{Zn}, \mathrm{Cu}$, and $\mathrm{B}$ in the plant organs was assessed to adjust three models. The first model described the phenological stages of vegetative growth, flower differentiation, and flowering. The other two models described the stages of fruit filling and harvest. All three models were established independently using the same design, factors and blocks to adjust the multivariate models. In addition, since there was no interaction between the factors, the statistical analysis included tests of variances between the control and other treatments to elucidate the effects of the treatments.

A descriptive interpretation was performed using the averages per treatment and phenological stage for each variable; these data are presented in the tables. SAS 9.3 (SAS Institute, Inc.), R, and Statgraphics Centurio XV (Statpoint Technologies, Inc.) were used for the data analysis.

\section{RESULTS AND DISCUSSION}

\section{Micronutrient accumulation in plants}

The multivariate analysis showed a significant interaction between the productive cycle and fertilizer treatment $(P<0.0001)$; in addition, statistical differences were seen between the treatments $(P<0.0001)$. The micronutrients, except $\mathrm{Cu}$, tended to increase in accumulation in whole plants at harvest (Tab. 1) as the doses of $\mathrm{N}$ fertilizers increased.

Table 1. Effect of $\mathbf{N}$ doses on micronutrient accumulation in banana cv. Williams at harvest in two production cycles.

\begin{tabular}{|c|c|c|c|c|c|}
\hline \multirow{2}{*}{$\begin{array}{c}\text { N dose } \\
\left(\mathrm{kg} \mathrm{ha}^{-1}\right)\end{array}$} & \multicolumn{5}{|c|}{ Micronutrient accumulation $\left(\mathrm{kg} \mathrm{ha}^{-1}\right)$} \\
\cline { 2 - 6 } & $\mathrm{Cu}$ & $\mathrm{Fe}$ & $\mathrm{Mn}$ & $\mathrm{Zn}$ & B \\
\hline Absolute control & 1.0 & 8.1 & 2.8 & 3.4 & 2.0 \\
\hline 0 & 0.2 & 5.7 & 2.4 & 1.6 & 1.5 \\
\hline 161 & 0.2 & 6.5 & 2.7 & 2.1 & 1.6 \\
\hline 321.8 & 0.2 & 7.9 & 2.3 & 2.4 & 2.2 \\
\hline 483 & 0.2 & 7.4 & 3.2 & 2.3 & 1.7 \\
\hline & & & Second cycle & \\
\hline Absolute control & 2.3 & 4.4 & 2.7 & 2.6 & 0.6 \\
\hline 0 & 4.3 & 4.8 & 2.0 & 2.1 & 0.5 \\
\hline 161 & 3.4 & 4.4 & 3.1 & 3.4 & 0.8 \\
\hline 321.8 & 3.3 & 5.3 & 3.0 & 3.3 & 0.9 \\
\hline 483 & 3.6 & 5.3 & 3.2 & 3.0 & 0.6 \\
\hline
\end{tabular}

This effect was not clear for the first cycle (Tab. 1), where the absolute control surpassed the other treatments in the accumulation of $\mathrm{Fe}, \mathrm{Zn}, \mathrm{Cu}$, and $\mathrm{B}$. This response could be associated with micronutrient retranslocation from the mother plant to the ratoon. The response for $\mathrm{Fe}$ and $\mathrm{Cu}$ could also be due to their high contents in Uraba soils. The higher $\mathrm{N}$ doses (321.8 and $483 \mathrm{~kg} \mathrm{ha}^{-1}$ ) provided the highest accumulation of micronutrients, except for $\mathrm{Cu}$, as compared to the control $\left(0 \mathrm{~kg} \mathrm{ha}^{-1} \mathrm{~N}\right)$. Copper had the highest accumulation in the absolute control, possibly because of the high initial content of $\mathrm{Cu}$ in the 
soils (ICA, 1992) and the absence of fertilizer applications in this treatment. According to Soto (2001), applications of phosphorus fertilizers can reduce $\mathrm{Cu}$ availability for plants because of the formation of $\mathrm{Cu}$ phosphates with low solubility in the soil, which may have happened in the other treatments, as compared to the absolute control.

For the second cycle, the accumulation of micronutrients increased as the $\mathrm{N}$ doses increased (Tab. 1), with a high accumulation of $\mathrm{Zn}$ and $\mathrm{B}$ at $321.8 \mathrm{~kg} \mathrm{~N}^{-1}$ and the highest Fe and $\mathrm{Mn}$ contents seen with $483 \mathrm{~kg}$ $\mathrm{ha}^{-1}$ of $\mathrm{N}$. Regardless of the micronutrient accumulation in the absolute control in the first cycle, the doses 321.8 and $483 \mathrm{~kg} \mathrm{ha}^{-1} \mathrm{~N}$ generated the highest accumulation for most micronutrients in the banana plants (Tab. 1). A similar result was found by Nyombi et al. (2010), who applied $400 \mathrm{~kg} \mathrm{ha}^{-1} \mathrm{~N}, 50 \mathrm{~kg} \mathrm{ha}^{-1} \mathrm{P}$, and $600 \mathrm{~kg} \mathrm{ha}^{-1} \mathrm{~K}$ and observed increased concentrations of mineral nutrients in banana plants.

The averaged sequence of micronutrient extraction by plants differed between the production cycles: $\mathrm{Fe}>\mathrm{Mn} \geq \mathrm{Zn}>\mathrm{B}>\mathrm{Cu}$ in the first cycle and $\mathrm{Fe}>\mathrm{Cu}>\mathrm{Mn} \geq \mathrm{Zn}>\mathrm{B}$ in the second one. The $\mathrm{Cu}$ accumulation changed substantially between the cycles. According to Havlin et al. (2013), at low water contents in the soil resulting from low precipitation, the concentration of $\mathrm{Cu}$ in the soil solution declines, and its adsorption by soil particles increases, which makes it more difficult for plants to absorb $\mathrm{Cu}$ than other nutrients. The conditions of the second cycle (high precipitation rate) were more favorable for $\mathrm{Cu}$ availability in the soil. Therefore, the differences in $\mathrm{Cu}$ accumulation between the cycles could be attributed to less $\mathrm{Cu}$ accumulation in plants under conditions of low precipitation (the first cycle) and to a higher accumulation of $\mathrm{Cu}$ in plants under more favorable climatic conditions (the second cycle).
The micronutrient accumulation in the plants in both cycles differed from that found by Rodríguez et al. (2004), Selvamani and Manivannan (2009), and Medina (2010). The differences, in most cases, were for the ratio of $\mathrm{Mn} / \mathrm{Fe}$ accumulation. These elements are typically accumulated in Musa plants with high contents, as compared to other micronutrients (Soto, 2001; Jeyabaskaran et al., 2018). There were notable differences from Medina (2010), who reported the accumulation sequence $\mathrm{Mn}>\mathrm{Fe}>\mathrm{Zn}>\mathrm{B}>\mathrm{Cu}$. This author worked with banana cv. Williams in a Fluvaquentic Eutrudepts soil, the same soil subgroup as two of the soils used in the present study (Soil Survey Staff, 2014) but with different fertilization practices (without micronutrient applications) and more favorable climatic conditions for plant cultivation, which might explain the differences in the micronutrient accumulations.

Table 2 compares the micronutrient accumulation in cv. Williams with data for banana Robusta (Walmsley and Twiford, 1976) and Cavendish (Lahav and Turner, 1992). Although these three cultivars belong to the same subgroup, Cavendish, the plants differed in the contents of micronutrients. Walmsley and Twiford (1976) reported a lower accumulation of micronutrients than Lahav and Turner (1992) and the present research, with the exception of $\mathrm{Mn}$. The lowest $\mathrm{Mn}$ content reported by Walmsley and Twiford (1976) fit the typical interval for $\mathrm{cv}$. Williams, while the highest $\mathrm{Mn}$ content was greater than the accumulation in $\mathrm{cv}$. Williams (Tab. 2). These data indicate that micronutrient accumulation in banana plants could vary depending on the cultivar, edaphoclimatic conditions, and agronomic practices, such as planting density and fertilization.

The highest doses of $\mathrm{N}$ fertilizers generated the highest production (Torres, 2016) and the highest levels of

Table 2. Micronutrient accumulation in banana cv. Williams for two production cycles in Uraba vs. micronutrient accumulation in bananas Robusta and Cavendish.

\begin{tabular}{|c|c|c|c|}
\hline \multirow{2}{*}{ Micronutrient } & cv. Williams & $\begin{array}{c}\text { Plants Robusta } \\
\text { (Walmsley and Twiford, 1976) }\end{array}$ & $\begin{array}{c}\text { Plants Cavendish } \\
\text { (Lahav and Turner, 1992) }\end{array}$ \\
\hline & \multicolumn{3}{|c|}{$\mathrm{kg} \mathrm{ha}^{-1}$ year $^{-1}$} \\
\hline $\mathrm{Fe}$ & $2.70-49.0$ & $1.0-1.1$ & 5.9 \\
\hline $\mathrm{Mn}$ & $1.20-1.99$ & $1.3-8.3$ & 12.5 \\
\hline $\mathrm{Cu}$ & $0.13-2.70$ & $0.053-0.073$ & 0.37 \\
\hline $\mathrm{Zn}$ & $1.0-2.12$ & $0.16-0.19$ & 4.7 \\
\hline$B$ & $0.34-1.37$ & $0.17-0.34$ & 1.27 \\
\hline
\end{tabular}


micronutrient accumulation (Tab. 1). The treatments with 321.8 and $483 \mathrm{~kg} \mathrm{ha}^{-1} \mathrm{~N}$ had better results. Soto (2001) and Robinson and Galán (2012) stated that, when increasing $\mathrm{N}$ doses, the absorption and accumulation of other mineral nutrients also increased, with consequent increases in production.

\section{Nutrient accumulation by organ and phenological stage}

Tables 3 illustrate the levels of micronutrient extraction by plant organ. The micronutrient contents in the roots were not included because these were negligible as compared to the other organs. Furthermore, the micronutrient concentration in roots might not always reflect plant requirements since metal micronutrients tend to precipitate on root surfaces and contribute to the formation of Fe plaque, especially when affected by changing redox regimes in tropical soils (Pi et al., 2010; Osorio, 2014).

\section{Corm}

Only the model for the harvest stage revealed the presence of significant differences $(P<0.0082)$ between the fertilizer treatments for $\mathrm{B}$ accumulation in the corm. No statistically significant effect from the $\mathrm{N}$ doses was found on the accumulation of other micronutrients in the corm during plant development. The descriptive analysis by development stage showed that, while the plants grew (Tab. 3), the accumulation of micronutrients in the corm varied. The doses of 321.8 and $483 \mathrm{~kg} \mathrm{ha}^{-1} \mathrm{~N}$ resulted in the highest accumulation of most micronutrients at each phenological stage, with the exception of $\mathrm{Cu}$ and $\mathrm{Mn}$, which had a reduced corm content with the dose of $321.8 \mathrm{~kg} \mathrm{~N} \mathrm{ha}^{-1}$ at flowering (Tab. 3).

Table 3. Effect of $\mathbf{N}$ doses on average content of micronutrients in corm of banana cv. Williams.

\begin{tabular}{|c|c|c|c|c|c|c|}
\hline \multirow{2}{*}{$\begin{array}{l}\text { Stage of } \\
\text { development }\end{array}$} & \multirow{2}{*}{$\begin{array}{c}\text { N dose } \\
\left(\mathrm{kg} \mathrm{ha}^{-1}\right)\end{array}$} & Cu & $\mathrm{Fe}$ & $\mathrm{Mn}$ & $\mathrm{Zn}$ & B \\
\hline & & \multicolumn{5}{|c|}{$\mathrm{mg} \mathrm{kg}^{-1}$ corm dry weight } \\
\hline \multirow{5}{*}{ Vegetative } & Absolute control & 128.9 & 117.4 & 98.6 & 88.2 & 21.6 \\
\hline & 0 & 102.5 & 174.4 & 78.3 & 71.1 & 31.8 \\
\hline & 161 & 139.8 & 132.5 & 102.0 & 104.9 & 39.4 \\
\hline & 321.8 & 93.5 & 126.2 & 78.8 & 89.2 & 31.9 \\
\hline & 483 & 156.1 & 189.5 & 104.0 & 89.1 & 24.0 \\
\hline \multirow{5}{*}{ Flower differentiation } & Absolute control & 144.7 & 133.2 & 115.7 & 128.2 & 36.0 \\
\hline & 0 & 132.7 & 167.1 & 62.2 & 81.8 & 25.1 \\
\hline & 161 & 164.6 & 123.9 & 63.0 & 72.9 & 32.1 \\
\hline & 321.8 & 180.0 & 128.3 & 98.2 & 94.9 & 21.8 \\
\hline & 483 & 147.9 & 150.8 & 86.7 & 124.7 & 22.6 \\
\hline \multirow{5}{*}{ Flowering } & Absolute control & 125.7 & 251.9 & 43.4 & 63.0 & 35.2 \\
\hline & 0 & 65.0 & 187.0 & 45.4 & 52.7 & 27.8 \\
\hline & 161 & 79.5 & 261.8 & 52.1 & 58.2 & 30.7 \\
\hline & 321.8 & 67.0 & 174.3 & 41.0 & 64.5 & 33.1 \\
\hline & 483 & 155.1 & 120.5 & 68.8 & 74.0 & 45.8 \\
\hline \multirow{5}{*}{ Fruit filling } & Absolute control & 141.7 & 101.2 & 86.9 & 110.8 & 14.6 \\
\hline & 0 & 95.8 & 94.4 & 51.2 & 59.2 & 20.5 \\
\hline & 161 & 86.0 & 99.9 & 44.5 & 67.0 & 25.5 \\
\hline & 321.8 & 89.8 & 167.7 & 51.4 & 66.4 & 19.4 \\
\hline & 483 & 128.2 & 117.0 & 66.3 & 71.3 & 11.5 \\
\hline \multirow{5}{*}{ Harvest } & Absolute control & 94.7 & 350.6 & 103.0 & 163.4 & 24.8 \\
\hline & 0 & 206.2 & 134.8 & 83.4 & 74.7 & 24.3 \\
\hline & 161 & 192.1 & 213.0 & 66.4 & 71.5 & 34.7 \\
\hline & 321.8 & 98.5 & 165.9 & 92.1 & 88.4 & 67.8 \\
\hline & 483 & 143.7 & 195.8 & 105.7 & 99.6 & 38.5 \\
\hline
\end{tabular}


Yang et al. (2013) used fertilizer rates of $385 \mathrm{~kg} \mathrm{~N}$ ha-1 and found the lowest accumulation of nutrients in the corm at harvest. However, in the present experiment, the control, $0 \mathrm{~kg} \mathrm{ha}^{-1} \mathrm{~N}$, had a higher accumulation of some nutrients in the corm in all stages of development (Tab. 3). This result could be attributed to nutrient recycling between the mother plant and the ratoon. Additionally, Fe and B might see less retranslocation from the corm, which is one of the main reserve organs (Galvis et al., 2013), since these elements has low mobility in the phloem (Marschner, 2012).

The micronutrient accumulation in the corm followed the order $\mathrm{Fe}>\mathrm{Cu}>\mathrm{Zn}>\mathrm{Mn}>\mathrm{B}$, which differed from that found by Walmsley and Twyford (1976) $(\mathrm{Mn}>\mathrm{Fe}>\mathrm{Zn}>\mathrm{B}>\mathrm{Cu})$ and Martínez (2006) $(\mathrm{Mn}>\mathrm{Fe}>\mathrm{B}>\mathrm{Cu}>\mathrm{Zn})$. The $\mathrm{cv}$. Williams corm contained 94.4-350 $\mathrm{mg} \mathrm{Fe} \mathrm{kg}^{-1}$ and 52.7-163.4 $\mathrm{mg} \mathrm{Zn} \mathrm{kg}^{-1}$
(Tab. 3), while Martínez (2006) found wider ranges of $73-880 \mathrm{mg} \mathrm{Fe} \mathrm{kg}^{-1}$ and 13-182 $\mathrm{mg} \mathrm{Zn} \mathrm{kg}^{-1}$. Walmsley and Twyford (1976) reported an accumulation of Fe (85-153 $\mathrm{mg} \mathrm{kg}^{-1}$ ) comparable to the present research, while the lowest level of $\mathrm{Zn}\left(19 \mathrm{mg} \mathrm{kg}^{-1}\right.$ ) (Walmsley and Twyford, 1976) was lower than found in cv. Williams. These results could be attributed to differences in soil conditions, crop management, cultivar, and fertilizer doses

\section{Pseudostem}

The models revealed differences between the fertilizer treatments at fruit filling $(P<0.00002)$ for the accumulation of $\mathrm{Zn}$ and at harvest $(P<0.0030)$ for the accumulation of $\mathrm{Cu}$ and $\mathrm{B}$. In general, the contents of $\mathrm{Fe}, \mathrm{Mn}$, and $\mathrm{Zn}$ in the pseudostem tended to increase during plant development (Tab. 4), similar to that reported by Jeyabaskaran et al. (2018). Increasing rates of

Table 4. Effect of $\mathbf{N}$ doses on average content of micronutrients in pseudostem of banana cv. Williams.

\begin{tabular}{|c|c|c|c|c|c|c|}
\hline \multirow{2}{*}{$\begin{array}{c}\text { Stage of } \\
\text { development }\end{array}$} & \multirow{2}{*}{$\begin{array}{l}\text { Nitrogen dose } \\
\left(\mathrm{kg} h \mathrm{a}^{-1}\right)\end{array}$} & $\mathrm{Cu}$ & Fe & $\mathrm{Mn}$ & $\mathrm{Zn}$ & B \\
\hline & & \multicolumn{5}{|c|}{$\mathrm{mg} \mathrm{kg}^{-1}$ pseudostem dry weight } \\
\hline \multirow{5}{*}{ Vegetative } & Absolute control & 71.3 & 532.1 & 165.7 & 68.8 & 35.9 \\
\hline & 0 & 80.2 & 804.5 & 140.4 & 85.8 & 38.8 \\
\hline & 161 & 114.8 & 418.9 & 174.9 & 69.7 & 48.7 \\
\hline & 321.8 & 69.8 & 447.4 & 183.0 & 70.4 & 41.7 \\
\hline & 483 & 122.8 & 445.2 & 169.7 & 68.6 & 44.4 \\
\hline \multirow{5}{*}{ Flower differentiation } & Absolute control & 133.4 & 229.6 & 110.4 & 71.5 & 39.2 \\
\hline & 0 & 81.6 & 152.8 & 103.2 & 59.5 & 35.9 \\
\hline & 161 & 198.1 & 215.3 & 109.2 & 59.1 & 43.3 \\
\hline & 321.8 & 170.5 & 240.4 & 111.5 & 60.1 & 27.4 \\
\hline & 483 & 172.4 & 228.8 & 132.0 & 65.2 & 44.3 \\
\hline \multirow{5}{*}{ Flowering } & Absolute control & 192.4 & 435.3 & 190.5 & 142.0 & 59.9 \\
\hline & 0 & 212.8 & 326.3 & 252.7 & 151.6 & 46.2 \\
\hline & 161 & 282.5 & 435.3 & 234.0 & 136.2 & 66.0 \\
\hline & 321.8 & 174.7 & 406.4 & 244.9 & 145.1 & 57.0 \\
\hline & 483 & 326.8 & 395.3 & 196.6 & 147.5 & 59.0 \\
\hline \multirow{5}{*}{ Fruit filling } & Absolute control & 20.3 & 374.3 & 254.5 & 180.0 & 123.1 \\
\hline & 0 & 14.1 & 319.0 & 230.5 & 217.7 & 148.3 \\
\hline & 161 & 16.1 & 396.5 & 232.7 & 195.7 & 104.7 \\
\hline & 321.8 & 14.9 & 806.0 & 224.8 & 182.5 & 117.8 \\
\hline & 483 & 16.7 & 383.5 & 248.4 & 202.8 & 119.1 \\
\hline \multirow{5}{*}{ Harvest } & Absolute control & 88.7 & 665.4 & 223.8 & 301.3 & 123.4 \\
\hline & 0 & 19.8 & 691.7 & 230.6 & 241.4 & 117.0 \\
\hline & 161 & 15.8 & 522.9 & 260.3 & 293.3 & 121.1 \\
\hline & 321.8 & 16.6 & 640.4 & 202.3 & 277.7 & 137.4 \\
\hline & 483 & 18.7 & 711.6 & 271.3 & 295.2 & 106.6 \\
\hline
\end{tabular}


$\mathrm{N}$, especially the doses 321.8 and $483 \mathrm{~kg} \mathrm{ha}^{-1} \mathrm{~N}$, had a positive effect on micronutrient accumulation in the pseudostem (Tab. 4). These results were similar to those of Castillo et al. (2011), who obtained the highest contents of mineral nutrients in the pseudostem with doses of $375 \mathrm{~kg} \mathrm{ha}^{-1} \mathrm{~N}$.

The sequence of micronutrient accumulation in the pseudostem changed from $\mathrm{Fe}>\mathrm{Mn}>\mathrm{Cu}>\mathrm{Zn}>\mathrm{B}$ at flowering to $\mathrm{Fe}>\mathrm{Zn}>\mathrm{Mn}>\mathrm{B}>\mathrm{Cu}$ at harvest. At both phenological stages, the data differed from those of Walmsley and Twyford (1976), Soto (2001), and Martínez (2006). These variations could be explained by interactions of environmental factors, soil, cultivar, and crop management, especially fertilization (Robinson and Galán, 2012). Additionally, the contents of elements in the pseudostem could vary between the cultivars depending on morphological differences in the distribution and configuration of vascular elements in the pseudostem (Souza et al., 2016).

\section{Leaves}

The nutrient accumulation models revealed significant differences between the fertilizer treatments at fruit filling $(P<0.0061)$ and harvest $(P<0.0387)$. The nutrients participating in the first model included $\mathrm{Cu}, \mathrm{Fe}$, and $\mathrm{Zn}$, and the second model included $\mathrm{Cu}$ and $\mathrm{B}$. The micronutrients differed in their accumulation in the leaves, with $\mathrm{Cu}$ contents that decreased and $\mathrm{Mn}$ contents that increased after flower differentiation (Tab. 5). The descriptive analysis showed that the $\mathrm{N}$ applications, especially at 321.8 and $483 \mathrm{~kg} \mathrm{ha}^{-1}$, favored a higher accumulation of the majority of the micronutrients in the leaves in all development stages, except flower differentiation (Tab. 5).

Table 5. Effect of $\mathbf{N}$ doses on average content of micronutrients in leaves of banana cv. Williams.

\begin{tabular}{|c|c|c|c|c|c|c|}
\hline \multirow{2}{*}{$\begin{array}{c}\text { Stage of } \\
\text { development }\end{array}$} & \multirow{2}{*}{$\begin{array}{c}\text { Nitrogen dose (kg } \\
\left(n a^{-1}\right)\end{array}$} & Cu & Fe & Mn & $\mathrm{Zn}$ & B \\
\hline & & \multicolumn{5}{|c|}{$\mathrm{mg} \mathrm{kg}^{-1}$ leaf dry weight } \\
\hline \multirow{5}{*}{ Vegetative } & Absolute control & 93.4 & 241.6 & 166.2 & 56.9 & 50.9 \\
\hline & 0 & 68.0 & 242.3 & 164.0 & 41.5 & 44.7 \\
\hline & 161 & 44.9 & 260.3 & 315.2 & 48.3 & 57.8 \\
\hline & 321.8 & 49.0 & 222.6 & 105.0 & 37.4 & 41.5 \\
\hline & 483 & 102.3 & 332.3 & 217.2 & 67.7 & 37.6 \\
\hline \multirow{5}{*}{ Flower differentiation } & Absolute control & 176.4 & 293.7 & 95.2 & 30.9 & 16.6 \\
\hline & 0 & 159.7 & 175.9 & 71.8 & 38.3 & 17.2 \\
\hline & 161 & 117.4 & 319.7 & 181.1 & 57.6 & 28.3 \\
\hline & 321.8 & 88.8 & 133.1 & 61.6 & 36.8 & 18.5 \\
\hline & 483 & 70.5 & 156.1 & 89.3 & 31.2 & 24.5 \\
\hline \multirow{5}{*}{ Flowering } & Absolute control & 66.6 & 257.5 & 100.2 & 36.9 & 13.2 \\
\hline & 0 & 79.8 & 273.7 & 104.0 & 59.0 & 16.5 \\
\hline & 161 & 45.9 & 227.0 & 111.6 & 28.0 & 12.3 \\
\hline & 321.8 & 147.2 & 288.2 & 101.1 & 54.6 & 16.0 \\
\hline & 483 & 71.6 & 293.8 & 105.3 & 61.1 & 19.4 \\
\hline \multirow{5}{*}{ Fruit filling } & Absolute control & 47.9 & 202.4 & 258.7 & 27.5 & 20.7 \\
\hline & 0 & 26.6 & 175.5 & 266.3 & 16.1 & 15.4 \\
\hline & 161 & 40.9 & 243.1 & 258.5 & 33.2 & 25.2 \\
\hline & 321.8 & 33.1 & 211.9 & 309.0 & 21.2 & 19.7 \\
\hline & 483 & 22.2 & 160.4 & 288.2 & 22.9 & 22.1 \\
\hline \multirow{5}{*}{ Harvest } & Absolute control & 37.7 & 221.6 & 379.4 & 201.8 & 118.8 \\
\hline & 0 & 29.8 & 223.6 & 285.8 & 67.9 & 43.7 \\
\hline & 161 & 39.1 & 226.9 & 376.5 & 166.0 & 85.2 \\
\hline & 321.8 & 38.8 & 263.8 & 316.0 & 145.7 & 75.1 \\
\hline & 483 & 40.1 & 285.9 & 404.9 & 80.8 & 45.7 \\
\hline
\end{tabular}


The higher doses of $\mathrm{N}$ (321.8 and $483 \mathrm{~kg} \mathrm{ha}^{-1}$ ) mostly contributed to the accumulation of $B$ in the leaves, as compared with $0 \mathrm{~kg} \mathrm{ha}^{-1} \mathrm{~N}$ (Tab. 5). The leaf contents of $\mathrm{B}$ and $\mathrm{Mn}$ could have highly significant, positive associations with the contents of $a, b$, and total chlorophyll, as observed in 'Prata' bananas (Arantes et al., 2016). This relationship is important since more than $70 \%$ of the leaf $\mathrm{N}$ could be a part of the chlorophyll molecules (Marschner, 2012).

The order of micronutrient accumulation in the leaves was $\mathrm{Mn}>\mathrm{Fe}>\mathrm{Cu}>\mathrm{Zn}>\mathrm{B}$, differing from the $\mathrm{Mn}>\mathrm{Fe}>\mathrm{B}>\mathrm{Zn}>\mathrm{Cu}$ reported by Walmsley and Twyford (1976), Soto (2001), and Martínez (2006), which could be attributed to the cultivar and practices. The ranges of micronutrient accumulation in the cv. Williams leaves differed from the literature data. For example, the Mn content was $61.6-404.9 \mathrm{mg} \mathrm{kg}^{-1}$ leaf DW (Tab. 5), while other authors reported 772-1945 (Walmsley and Twyford, 1976) and $867 \mathrm{mg} \mathrm{kg}^{-1}$ leaf DW (Soto, 2001).

Leaves are source organs for fruit filling (Soto, 2001). However, high doses of $\mathrm{N}$ could promote excessive leaf growth and favor a greater accumulation of $\mathrm{N}$ in leaves, i.e. plants allocate more $\mathrm{N}$ in leaves than in fruit formation, resulting in low productivity (Deus et al., 2020). The increased accumulation of $\mathrm{Mn}$ and $\mathrm{B}$ in the cv. Williams leaves at the higher $\mathrm{N}$ doses (Tab. 5) could be due to increased rates of leaf growth; thus, the leaves might have demanded greater amounts of micronutrients for growth when stimulated by high $\mathrm{N}$ rates.

\section{Bunch}

The model obtained at the harvest stage revealed differences between the fertilizer treatments $(P<0.0007)$ for the accumulation of $\mathrm{Mn}$ and $\mathrm{Cu}$ in the bunches. At both development stages (fruit filling and harvest), the higher doses of $\mathrm{N}$ favored micronutrient accumulation in the fruits (Tab. 6) and increased fruit yield (Torres, 2016). Increasing the doses of $\mathrm{N}$ fertilizers most highly stimulated $\mathrm{Zn}$ accumulation in the bunches, as compared to other micronutrients. While the $\mathrm{B}$ contents diminished during fruit formation, the $\mathrm{Mn}$ contents decreased when increasing $\mathrm{N}$ doses at fruit filling, which increased at harvest (Tab. 6).

The fruits accumulated micronutrients in the sequence $\mathrm{Fe}>\mathrm{Cu}>\mathrm{Zn}>\mathrm{Mn}>\mathrm{B}$, differing from the sequences $\mathrm{Mn}>\mathrm{Fe}>\mathrm{B}>\mathrm{Zn}>\mathrm{Cu}$ (Walmsley and Twyford, 1976), $\mathrm{Fe}>\mathrm{Zn} \approx \mathrm{Mn}>\mathrm{Cu}$ (Forster et al., 2002), and $\mathrm{Mn}>\mathrm{Fe}>\mathrm{Zn}>\mathrm{B}>\mathrm{Cu}$ (Yang et al., 2013); additionally, the contents of $\mathrm{Cu}, \mathrm{Zn}$ and $\mathrm{B}$ in the $\mathrm{cv}$. Williams fruits (Tab. 6) exceeded those reported for other cultivars (3-10.2, 4-49.2, and 9-23.6 $\mathrm{mg} \mathrm{kg}^{-1}$ bunch for $\mathrm{Cu}, \mathrm{Zn}$, and B, respectively) (Walmsley and Twyford, 1976; Yang et al., 2013).

Micronutrient accumulation in fruits is important for fruit formation and quality (Robinson and Galán, 2002; Pareek, 2016). Despite the differences in the micronutrient accumulation in the fruits between the $\mathrm{N}$ treatments during the two production cycles, these was no effect on the fruit export quality in terms of postharvest fruit duration or peel splitting (data not shown). In the tropics, banana

Table 6. Effect of $\mathbf{N}$ doses on average contents of micronutrients in bunches of banana cv. Williams.

\begin{tabular}{|c|c|c|c|c|c|c|}
\hline \multirow{2}{*}{$\begin{array}{c}\text { Stage of } \\
\text { development }\end{array}$} & \multirow{2}{*}{$\begin{array}{l}\text { Nitrogen dose (kg } \\
\left.\text { ha }^{-1}\right)\end{array}$} & Cu & $\mathrm{Fe}$ & Mn & $\mathrm{Zn}$ & B \\
\hline & & \multicolumn{5}{|c|}{$\mathrm{mg} \mathrm{kg}^{-1}$ bunch dry weight } \\
\hline \multirow{5}{*}{ Fruit filling } & Absolute control & 137.7 & 331.6 & 126.1 & 136.0 & 102.8 \\
\hline & 0 & 232.3 & 300.6 & 139.7 & 156.1 & 103.7 \\
\hline & 161 & 153.5 & 343.8 & 131.4 & 163.5 & 67.4 \\
\hline & 321.8 & 166.7 & 696.8 & 129.0 & 168.8 & 104.4 \\
\hline & 483 & 185.1 & 313.8 & 118.4 & 151.3 & 89.7 \\
\hline \multirow{5}{*}{ Harvest } & Absolute control & 116.0 & 214.3 & 92.8 & 101.2 & 66.5 \\
\hline & 0 & 261.2 & 262.2 & 92.9 & 92.6 & 71.2 \\
\hline & 161 & 166.9 & 324.9 & 137.8 & 153.6 & 64.6 \\
\hline & 321.8 & 183.2 & 211.9 & 78.1 & 96.4 & 53.5 \\
\hline & 483 & 142.8 & 267.4 & 133.4 & 125.9 & 69.5 \\
\hline
\end{tabular}


fruits could serve as a source of micronutrients, especially $\mathrm{Mn}, \mathrm{Fe}$, and Zn, for human diets (Pareek, 2016; Ashokkumar et al., 2018). According to our results, increasing the rates of $\mathrm{N}$ applications favored to the accumulation of the majority of the micronutrients in the cv. Williams fruits. More research should be conducted for more than two cycles to assess micronutrient accumulation and distribution in banana plants with ratoons from three or more generations.

\section{CONCLUSIONS}

Increasing the doses of $\mathrm{N}$ fertilizer in the two production cycles increased the levels of micronutrient accumulation in the cv. Williams banana plants, including the fruits. The better rates of $\mathrm{N}$ fertilizers for the highest accumulation of $\mathrm{Cu}, \mathrm{Fe}, \mathrm{Mn}, \mathrm{Zn}$, and $\mathrm{B}$ in the plants were 321.8 and $483 \mathrm{~kg} \mathrm{ha}^{-1} \mathrm{~N}$.

The averaged sequences of micronutrient extraction by whole plants differed between the production cycles: $\mathrm{Fe}>\mathrm{Mn} \geq \mathrm{Zn}>\mathrm{B}>\mathrm{Cu}$ in the first cycle and $\mathrm{Fe}>\mathrm{Cu}>\mathrm{Mn} \geq \mathrm{Zn}>\mathrm{B}$ in the second one. The sequence of micronutrient accumulation in the organs was organ-specific and varied in each organ, depending on the stage of development.

Conflict of interests: The manuscript was prepared and reviewed with the participation of the authors, who declare that there exists no conflict of interest that puts at risk the validity of the presented results.

\section{BIBLIOGRAFIC REFERENCES}

Alcaraz, J.J. and J.G. Jiménez. 2018. La aplicación de la agricultura de precisión en el proceso de fertilización: un caso de estudio para el sector bananero del Urabá-Antioqueño. MSc thesis. Program in Applied Economy, Universidad EAFIT, Medellin, Colombia.

Arantes, A.D.M., S.L. Donato, D.L.D. Siqueira, E.P. Amorim, and V.A. Rodrigues Filho. 2016. Chlorophyll index for real-time prediction of nutritional status of 'Prata' banana. Rev. Bras. Eng. Agríc. Ambient. 20(2), 99-106. Doi: 10.1590/1807-1929/agriambi.v20n2p99-106

Ashokkumar, K., S. Elayabalan, V.G. Shobana, P. Sivakumar, and M. Pandiyan. 2018. Nutritional value of cultivars of Banana (Musa spp.) and its future prospects. J. Pharmacog. Phytochem. 7(3), 2972-2977.

AUGURA. 2020. Coyuntura bananera 2019. Medellin, Colombia.
Borges, A.L., S. Oliveira, R. Corrēa, and C. Silva. 2006. Teores foliares de nutrientes em genótipos de bananeira. Rev. Bras. Frutic. 28(2), 314-318. Doi: 10.1590/ S0100-29452006000200036

Castillo, A.M., J.A. Hernández, E. Avitia, J. Pineda, L.A. Valdéz, and T. Corona. 2011. Extracción de macronutrientes en banano 'Dominico' (Musa spp.). Rev. Int. Bot. Exp. 80, 65-72. Doi: 10.32604/phyton.2011.80.065

Deus, J.A., J.C.L. Neves, A.J.D. Lima Neto, W. Natale, V. V.H. Alvarez, and F.M. Albuquerque. 2020. Partitioning of macronutrients and nutritional efficiency in fertigated Prata banana. Rev. Bras. Frutic. 42(4), e-611. Doi: 10.1590/0100-29452020611

Forster, M.P., E. Rodriguez, J.D. Martián, and C.D. Romero. 2002. Statistical differentiation of bananas according to their mineral composition. J. Agric. Food Chem. 50(21), 6130-6135. Doi: 10.1021/jf0255578

Galvis, F., A. Uribe, G. Cayón, S. Magnitskiy, and J.S. Henao. 2013. Effect of fertilizer insertion in the harvested mother banana plant pseudostem (Musa AAA Simmonds). Agron. Colomb. 31(1), 103-111.

Guimarães, G.G.F., R.R. Cantú, R.F. Scherer, A.B. Beltrame, and M.M.D. Haro. 2020. Banana crop nutrition: insights into different nutrient sources and soil fertilizer application strategies. Rev. Bras. Ciênc. Solo 44, e0190104. Doi: 10.36783/18069657rbcs20190104

Gutiérrez, D.P., V.H. Nauzan, and G.A. Díaz. 2017. The efficiency wages in the Urabá banana sector-Colombia. Rev. Econ. Caribe 20, 7-26.

Havlin, J.L., S.L. Tisdale, W.L. Nelson, and J.D. Beaton. 2013. Soil fertility and fertilizers: An introduction to nutrient management. $8^{\text {th }}$ ed., Pearson Prentice Hall, NJ.

ICA, Instituto Colombiana Agropecuario. 1992. Fertilización en diversos cultivos. Quinta aproximación. Manual Técnico No. 25. Mosquera, Colombia.

IGAC, Instituto Geográfico Agustín Codazzi. 2006. Manual de métodos analíticos de laboratorio de suelos. $6^{\text {th }} \mathrm{ed}$. Bogota.

Jeyabaskaran, K.J., R. Pitchaimuthu, and S. Uma. 2018. Assessing nutrient uptake pattern with respect to dry matter accumulation in Ney Poovan (AB) banana at critical growth stages. Indian J. Hortic. 75(3), 405-410. Doi: 10.5958/0974-0112.2018.00069.5

Johnson, R. and D. Wichern. 2007. Applied multivariate statistical analysis. $6^{\text {th }}$ ed. Prentice Hall, Upper Saddle River, NJ.

Keshavan, G., M. Kavino, and V. Ponnuswami. 2014. Influence of different nitrogen sources and levels on yield and quality of banana (Musa spp.). Arch. Agron. Soil Sci. 57(3), 305-315. Doi: 10.1080/03650340903302286

Kumar, S., P. Kumawat, and M. Suman. 2020. A review on role of micronutrients on banana, mango and pomegranate. Int. J. Pure Appl. Biosci. 8(1), 190-198. Doi: 10.18782/2582-2845.7949 
Lahav, E. and D. Turner. 1992. Fertilización del banano para rendimientos altos. $2^{\text {nd }}$ ed. Inpofos Boletín 7, Quito.

Liu, F., I. Lin, I. Zhang, X. Fan, and S. Sun. 2019. Effects of $\mathrm{N}$ deficiency and resupply of $\mathrm{N}$ nutrient on banana growth and root morphological parameters. J. Fruit Sci. 1, 1-9.

Marschner, H. 2012. Mineral nutrition of higher plants. $3^{\text {rd }}$ ed. Academic Press, San Diego, CA.

Martínez, A. 2006. Dinámica de la distribución de nutrientes durante el desarrollo de la planta de banano (Musa AAA Simmonds cvs. Gran Enano y Valery). MSc thesis, Facultad de Agronomía, Universidad Nacional de Colombia, Bogota.

Medina, L. 2010. Curvas de absorción de nutrientes en una plantación establecida de banano (Musa AAA). cv Williams, pp. 314-321. In: Gracía, N.L. and J.J. Mira. (eds.). Proc. XIX Congreso de Acorbat, Medellin, Colombia.

Nyombi, K., P.J. Van Asten, M. Corbeels, G. Taulya, P.A. Leffelaar, and K.E. Giller. 2010. Mineral fertilizer response and nutrient use efficiencies of East African highland banana (Musa spp., AAA-EAHB, cv. Kisansa). Field Crops Res. 117(1), 38-50. Doi: 10.1016/j. fcr.2010.01.011

Osorio, N.W. 2014. Manejo de los nutrientes en suelos del trópico. $2^{\text {nd }}$ ed. L. Vieco, Medellin, Colombia.

Pareek, S. 2016. Nutritional and biochemical composition of banana (Musa spp.) cultivars. pp. 49-81. In: Simmonds, M. and V.R. Preedy (eds.). Nutritional composition of fruit cultivars. Academic Press, New York, NY. Doi: 10.1016/B978-0-12-408117-8.00003-9

Perea, M. 2003. Biotecnología: Bananos y plátanos. Editora Guadalupe, Bogota.

Pi, N., N.F.Y. Tam, and M.H. Wong. 2010. Effects of wastewater discharge on formation of Fe plaque on root surface and radial oxygen loss of mangrove roots. Environ. Pollut. 158(2), 381-387. Doi: 10.1016/j. envpol.2009.09.004

Red Agricola. 2020. Retos y desafíos del sector bananero colombiano. https://www.redagricola.com/co/retos-y-desafios-del-sector-bananero-colombiano/; consulted: August, 2020.

Robinson, J.C. and V. Galán. 2012. Plátanos y bananos. $2^{\text {nd }}$ ed. Mundi-Prensa, Madrid.

Rodríguez, V., E. Malavolta, A. Sánchez, and O. Lavoranti. 2004. Balance nutricional de referencia de suelos y hoja en el cultivo del plátano Hartón. Bioagro 16(1), 39-46.

Sánchez, T.J.D. and J. Mira. 2013. Principios para la nutrición del banano. AUGURA; Cenibanano, Medellin, Colombia.

Selvamani, P. and K. Manivannan. 2009. Effect of organic manures, inorganic fertilizers and biofertilizers on the nutrient concentration in leaves at different growth stages of banana cv. Poovan. J. Phytol. 1(6), 381-387.

Soil Survey Staff. 2014. Keys to soil taxonomy. $12^{\text {th }}$ ed. USDA Soil Conservation Service, Washington, DC.

Souza, B.P.D., E.D.B. Silva, M. Cruz, M.D. Céu, E.P. Amorim, and S.L.R. Donato. 2016. Micronutrients deficiency on the nutritional status of banana Prata seedlings. Rev. Bras. Frutic. 38(3), e-884. Doi: 10.1590/0100-29452016884

Soto, M. 2001. Banano: Técnicas de producción. Universidad de Costa Rica, San Jose.

Torres, J. 2016. Absorción, distribución y acumulación de nitrógeno en banano variedad Williams en dos ciclos de producción en zona húmeda tropical. PhD thesis. Facultad Ciencias Agrarias, Universidad Nacional de Colombia, Bogota.

Torres, J., S. Magnitskiy, and J.D. Sánchez. 2019. Effect of fertilization with $\mathrm{N}$ on height, number of leaves, and leaf area in banana (Musa AAA Simmonds, cv. Williams). Rev. Colomb. Cienc. Hortic. 13(1), 9-17. Doi: 10.17584/rcch.2019v13i1.8440

Turner, D.W., D.J. Gibbs, W. Ocimati, and G. Blomme. 2020. The suckering behaviour of plantains (Musa, $\mathrm{AAB}$ ) can be viewed as part of an evolved reproductive strategy. Sci. Hortic. 261, 108975. Doi: 10.1016/j. scienta.2019.108975

Villaseñor, D., R.D.M. Prado, G.P. Silva, M. Carrillo, and W. Durango. 2020. DRIS norms and limiting nutrients in banana cultivation in the South of Ecuador. J. Plant Nutr. 43(18), 2785-2796. Doi: 10.1080/01904167.2020.1793183

Walmsley, D. and I.T. Twyford. 1976. The mineral composition of the Robusta banana. V. Sulphur, iron, manganese, boron, zinc, copper, sodium and aluminium. Plant Soil 45, 595-611. Doi: 10.1007/BF00010582

Yang, B., L. Yao, G. Li, C. Zhou, Z. He, and S. Tu. 2013. Absorption, accumulation and distribution of mineral elements in plantain banana. J. Plant Nutr. Fertil. 19(6), 1471-1476. 